\title{
ИВАН ИВАНОВИЧ АВДЕЕВ - ИССЛЕДОВАТЕЛЬ, ЭТНОГРАФ, НАУЧНЫЙ СОТРУДНИК ТОБОЛЬСКОГО МУЗЕЯ
}

\section{IVAN IVANOVICH AVDEEV-RESEARCHER, ETHNOGRAPHER, RESEARCHER AT THE TOBOLSK MUSEUM}

Ya. Abdullina

Summary:The article deals with the research activities of the ethnographer Ivan Ivanovich Avdeev in the Tobolsk Museum. Researcher I.I. Avdeev drew attention to the need to complete the museum collection on the Siberian Tatars. As a result, an ethnographic collection was collected, reflecting the history and life of the Tatars who lived in the Tobolsk district. I.I. Avdeev studied the folklore of the Khanty and Mansi. During the period of the historical expeditions to the Khanty and Mansi, the researcher collected exhibits and documents representing the religious views of the northern peoples. In 1937 I.I. Avdeev published the book "Songs of the Mansi People». The article is based on previously unknown archival materials, and reveals the scientific heritage of I.I. Avdeev in the Tobolsk Historical and Architectural Museum-Reserve.

Keywords: I.I. Avdeev, Tobolsk Museum, Tobolsk Tatars, Mansi folklore, bear songs, ethnographer.

\section{Введение}

$\mathrm{T}$ обольский музей с самого своего основания был посвящен народам Севера Тобольской губернии. Благодаря научно-исследовательской работе музейных сотрудников этнографическое собрание Тобольского историко-архитектурного музея-заповедника насчитывает более 3000 тысяч единиц хранения. [4]. На современном этапе собраны значительные музейные коллекции по традиционной культуре народов Западной Сибири: самодийцев (тундровых и лесных ненцев, селькупов), обских угров (ханты и манси), коми, сибирских татар и бухарцев. Этнографическое собрание Тобольского историко-архитектурного музея-заповедника формировалось на протяжении всего минувшего столетия. Огромный вклад в пополнение и изучение коллекций по традиционной культуре народов Северо-Западной Сибири внесли сотрудники музея. Одним из активных сотрудников Тобольского музея был Иван Иванович Авдеев (1912-1937), внесший вклад в изучение народов Севера и Сибири, а также способствовавший пополнению музейных коллекций в 1930-е гг. Биография сотрудника музея практически неизвестна. Данная статья посвящена научно-исследовательской работе И.И. Авдеева в Тобольском музее.

\author{
Абдуллина Яна Борисовна \\ Главный специалист, Тобольский \\ историко-архитектурный музей-заповедник \\ yana.abdullina.92@mail.ru
}

Аннотация: В статье рассмотрена научно-исследовательская деятельность этнографа Ивана Ивановича Авдеева в Тобольском музее. Исследователь И.И. Авдеев обращал внимание на необходимость пополнения музейной коллекции по сибирским татарам в Тобольском музее. Благодаря И.И. Авдееву в музее было скомплектовано этнографическое собрание, отражающее историю и быт татар, проживавших в Тобольском районе. И.И. Авдеев занимался изучением фольклора ханты и манси. После проведения историкобытовых экспедиций к ханты и манси были изучены религиозные воззрения северных народов. Результаты экспедиций к манси были опубликованы в книге «Песни народов манси». Статья основана на ранее неизвестных архивных материалах, и раскрывает научное наследие И.И. Авдеева в Тобольском историко-архитектурном музее-заповеднике.

Ключевые слова: И.И. Авдеев, Тобольский музей, тобольские татары, фольклор манси, медвежьи песни, этнограф.

В основу статьи положены ранее неизвестные материалы. Это документы архивного фонда «Тобольский государственный историко-архитектурный музей-заповедник» Государственного архива в г. Тобольске: протоколы рабочих совещаний сотрудников музея. [6]. В работе были использованы документы, хранящиеся в научном архиве Тобольского музея, составленные И.И. Авдеевым: «План и содержание работы научного сотрудника Тобольского музея - Авдеева во время экспедиции к татарам Тобольского района от 23 декабря 1935 г.» [15] , «Смета на командировку к Тобольским татарам научного сотрудника музея Авдеева от 22 декабря 1936 г.» [16], «Акт от 4 июня 1937 года о передаче этнографических материалов в Тобольский музей» [5], а также переписка, планы и отчёты работы музея с 1935 по 1937 годы.

Иван Иванович Авдеев был принят научным сотрудником в Тобольский музей 25 марта 1935 года. И.И. Авдеев занимался изучением производительных и природных богатств Тобольского Севера, исследовал культуру и быт народов Севера и Сибири, способствовал пополнению музейного фонда, а также поддерживал связи с научно-исследовательскими центрами Областного Бюро краеведения и хозяйственными учреждениями края. [13]. В документе «Личный состав Тобольского государственного музея за 1935 г.» приводится информация о 
том, что двадцатитрехлетний научный сотрудник И.И. Авдеев имел высшее образование, ни к одной политической партии не относился, проживал по адресу: город Тобольск, улица Большая Октябрьская, дом 10. [17]. Областью научных исследований в Тобольском музее И.И. Авдеева был фольклор северных народов Остяко-Вогульского округа, а также научный сотрудник занимался исследованием культуры и быта татар Тобольского района.

\section{Историко-бытовая экспедишия к татарам Тобольского района}

В 1934 году Тобольский музей посетил советский этнограф, научный сотрудник Ленинградского отделения Института этнографии Академии Наук СССР - Сергей Васильевич Иванов. В журнале «Советская этнография» В 1935 г. была опубликована статья «По музеям Западной Сибири», где исследователь знакомил читателей с музеями Западной Сибири, а также с экспозицией и техникой работой музеев на местах.С.В.Иванов упомянул в работе, что по богатству и ценности этнографических коллекций Тобольский музей занимает одно из первых мест среди музеев Западной Сибири, гордость музея составляет богатое собрание старинной одежды ханты, хранящееся в фондах. С.В. Иванов выделял ценные коллекции предметов, относящихся к эпохе атамана Ермака Тимофеевича: кольчуги, шлемы, оружие и т.д. Однако этнограф С.В. Иванов признал факт, что в музее отсутствуют коллекции по тобольским татарам, живущим не только в окрестностях Тобольска, но и в самом городе. Исследователь выделил отдельные предметы, которые характеризовали одежду, украшения и посуду зажиточной верхушки татарского общества. По мнению С.В. Иванова, отсутствовали музейные предметы, представляющие хозяйство и занятия сибирских татар. Ввиду отсутствия коллекций по тобольским и тюменским татарам в других музеях Сибири, а также в центральных музеях Советского Союза, вставал вопрос о немедленном пополнении этнографических коллекций по сибирским татарам в Тобольском музее. [9, с. 115]. В 1935 году И.И. Авдеев на производственном совещании в музее обосновал необходимость историко-бытовой экспедиции в места проживания тобольских татар. [14]. В документе «План и содержание работы научного сотрудника Тобольского музея - Авдеева во время экспедиции к татарам Тобольского района от 23 декабря 1935 г.», исследователь писал, что этнография может оказаться перед печальным фактом полного отсутствия вещевых материалов, характеризующих хозяйство, быт и верования народа, игравшего столь значительную роль в истории Сибири. И.И. Авдеев отмечал важность изучения истории и культуры татар Западной Сибири в этнографическом, фольклорном и лингвистическом отношении. Историко-бытовая экспедиция к тобольским татарам была запланирована на один месяц с 5 января 1935 по 2 февраля 1935 год (Рис.1). Маршрут экспедиции был проложен в районы обитания заболотных татар: Вармахлинские юрты, затем Лаймовские юрты Тобольского района. Исследователь выделил этот район, как место обитания так называемых заболотных татар, и назвал их «отатарившиеся остяки». Из-за географического соседства заболотных татар и ханты, И.И. Авдеев в своем историко-этнографическом очерке о сибирских татарах, выдвигал гипотезу об участии самодийского населения в этногенезе жителей Заболотья. [15].

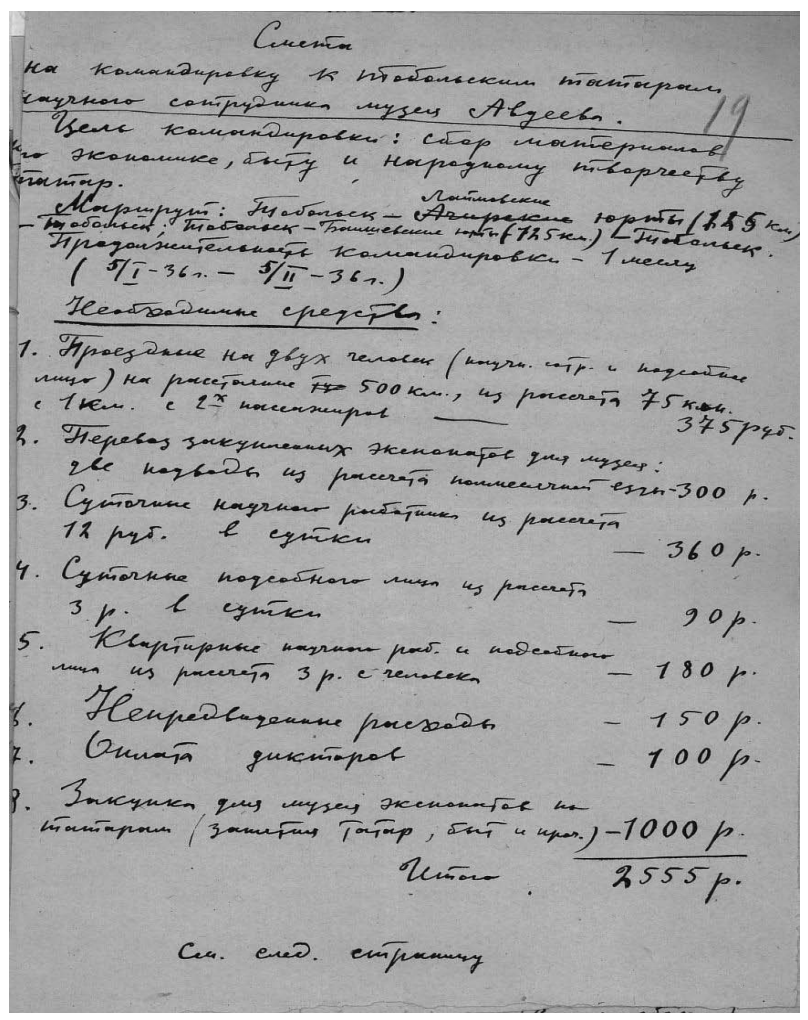

Рис. 1. Смета на командировку к тобольским татарам научного сотрудника музея Авдеева от 22 декабря 1936. НА-420/13.

Fig. 1. The estimate for trip to Tobolsk Tatars of researcher Avdeev from December 22, 1936.

Этнографическое исследование проводилось по следующим вопросам: общие данные об обследуемом районе (природа, численность населения, основные цифровые показатели по экономике, культуре и сельсоветам), занятия населения (сельское хозяйство, животноводство, охота, рыбная ловля), ремесла, жилища и постройки, пища, одежда, способы и средства передвижения, семья, религия. Иван Иванович Авдеев занимался сравнением татарских и хантыйских орудий охоты и рыбной ловли, жилищ, утвари, религиозных верований и языков. Методы работы экспедиции были построены на наблюдении и описании, широко использовал научный сотрудник метод опроса населения и метод фиксации изучаемого через фотографии и чертежи. Для Тобольского музея приобретались предметы охоты: дробовик старого образца, деревянная пороховница, кожаный ко- 
шелек для дроби и пороха, мерка для пороха и дроби, патронташ, лыжи, различного рода западни и силки. [15]. В ходе экспедиции были приобретены предметы, связанные с животноводством (арканы для ловли лошадей, орудия клеймения, конная сбруя), с одеждой (мужские бешметы, рубахи, шаровары, шапки, женские предметы одежды и проч.), с внутренним убранством татарского жилища и домашней утварью (фиксировалось характерное месторасположение каждого предмета в доме), с религией (коврики для молящихся, четки, кувшины для омовения, шамаилы, священные книги), с музыкальным творчеством татар (музыкальный инструмент «кубыз», рис. 2). После завершения экспедиции И.И. Авдеевым были переданы в музей рисунки школьников Тобольского района. Помимо предметного ряда был собран татарский фольклор. И.И. Авдеев выделил три этапа развития фольклора тобольских татар: фольклор, уходящий в «дорусский» период татар, фольклор дореволюционного периода, фольклор о революции, В.И. Ленине, И.В. Сталине. [11].

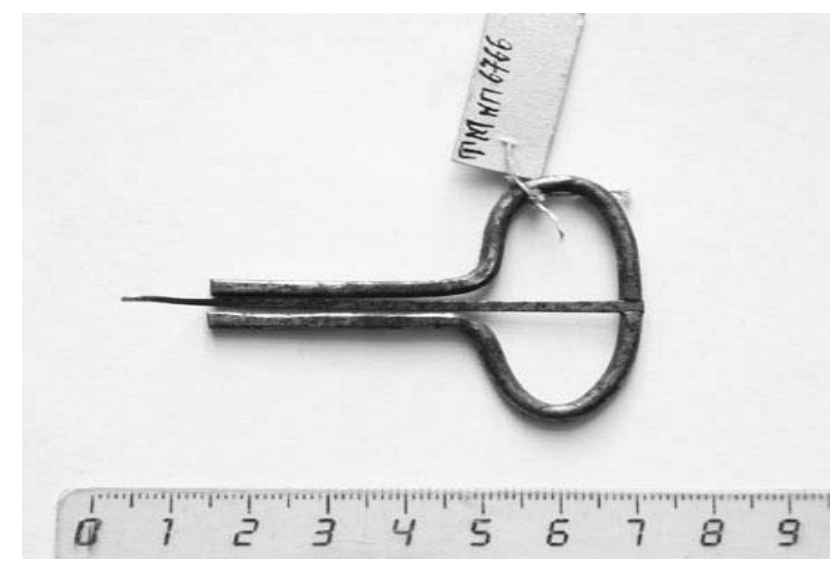

Рис. 2. Музыкальный инструмент - кубыз. Татары. Дата поступления в музей 23.01.1936 г. ТМ-6766.

Fig. 2. Musical instrument - kubyz. Tatars. Date of admission to the museum $01 / 23 / 1936$

В 1936 г. И.И. Авдеев на средства Областного Бюро Краеведения совершил длительную научную командировку к тобольским татарам Тобольского района. В результате была собрана большая этнографическая коллекция - 230 предметов по традиционному быту тобольских татар. Также были собраны предметы, связанные с послереволюционным временем [11]. Результаты историко-бытовой экспедиции были опубликованы в историко-этнографическом очерке «Тобольские и тюменские татары» [3]. Благодаря организации и проведению историко-бытовой экспедиции был сформирован предметный ряд, представлявший быт татар Тобольского района, результаты исследовательской работы нашли отражение в историко-этнографическом очерке. Период с 1935 по 1937 год стал временем комплектования коллекций по истории и культуре сибирских татар.
В 1936 году от Тобольского музея Омскому Областному Бюро Краеведения было направлено официальное письмо на финансирование археологических работ в районе реки Лайма с 15 июня по 1 августа 1936 года. С целью изучения северного Обь-Иртышья в археологическом отношении была необходима научно-исследовательская работа по изучению истории северных народностей. В составе экспедиции были отмечены этнограф И.И. Авдеев, археолог И.Д. Смирнов и геолог А.Г. Фокин. Тобольский музей и Окружное Бюро Краеведения выделяли в качестве исследования археологические памятники по району реки Лайма. Эта территория была выявлена в ходе экспедиции И.И. Авдеева к татарам в 1936 году. В документе было отмечено, что территория реки Лайма была совершенно не обследована и изучена в археологическом отношении, в районе реки располагались многочисленные археологические памятники, относящиеся к первоначальным насельникам края и всем последующим (сабиры, ненцы, манси, татары), на основе изучения местности можно было проследить историю заселения края на протяжении 2000-3000 лет [18]. Район реки Лайма был отмечен И.И. Авдеевым, как территория компактного проживания заболотных татар. В своем историко-этнографическом очерке Авдеев писал: «Богатые и обширные охотничьи и рыболовные угодья северной части Тобольского округа (бассейны рек Носка, Лайма, Иземеть, Вачир) обусловили развитие у живущих там, так называемых заболотных татар, охотничьего и рыболовного промысла» [3, с. 14]. Однако из-за отсутствия финансовой поддержки археологическая экспедиция не была реализована.

\section{Изучение И.И. Авцеевым фольклора народов Севера}

В 1936 году И.И. Авдеевым была организована экспедиция в Остяко-Вогульский округ [11]. Был исследован обширный материал по социально-экономической жизни ханты и манси, который включал разделы: 1) социальное переустройство хозяйства ханты и манси; 2) работа Казымской культбазы; 3) об истории ханты и манси. За период научной экспедиции к ханты и манси было собрано 70 экспонатов и документов, характеризующих подъем хантыйской и мансийской культуры в период советской власти, 29 экспонатов, отражающих религиозные воззрения ханты и манси, а также было собрано около 400 рукописных листов фольклора северных народов. Собранные вещественные, документальные материалы должны были быть положены в основу организуемого в 1937 году Тобольским музеем нового отдела «Северная Арктика» [12]. В протоколе производственного совещания сотрудников Тобольского музея от 27 ноября 1936 года было отмечено о необходимости научному сотруднику И.И. Авдееву написать о результатах этнографической экспедиции на Север в журнале «Советский музей» $[6]$. 
В научном архиве Тобольского музея-заповедника хранится документ «Фольклор ханты и манси», составленный И.И. Авдеевым. [19]. В этом документе исследователь рассматривал основные виды фольклора: мифологическая и космогоническая поэзия, героический эпос, песни и драматические представления медвежьего праздника, сказки, рассказы, предания, лирическая поэзия, охотничьи и рыболовные заговоры, загадки. И.И. Авдеев отмечал, что ханты и манси, одни из наиболее одаренных поэтически народностей Севера, которые создавали и хранили богатейший фольклор. Фольклор ханты и манси необходимо собирать изучать, по мнению этнографа, северные народы длительный период не имели своей письменности, фольклор выступал как основной источник для познания истории народа, мировоззрения, психологии. В работе были напечатаны хантыйские и мансийские национальные фольклорные тексты с переводом на русский язык. Большинство текстов были записаны летом 1936 года в период экспедиции к ханты и манси в Остяко-Вогульский национальный округ, организованной Тобольским музеем и Омским областным издательством. Документ делится на следующие разделы:хантыйские и мансийские былины; хантыйский и мансийский фольклор медвежьего праздника, хантыйские и мансийские сказки и рассказы; советский фольклор. Фольклор манси и ханты был родственен, почти идентичен, как по стилю, так по и содержанию. Хантыйские тексты были записаны на шеркальском и казымском диалектах. Мансийсие песни были записаны у обских манси, а также у сосьвинских и ляпинских манси. В основу транскрипции были положены хантыйский и мансийский алфавиты, разработанные Научно-исследовательской ассоциацией Института народов Севера им. П. Смидовича [19].

После завершения двух научных экспедиций И.И. Авдеев разработал план научно-исследовательской работы музея, куда включил следующие темы: «Социальные структуры общества ханты и манси до прихода русских», «Пережитки родового строя у народностей Тобольского Севера», «Быт тобольских татар до революции и после революции», «Казымская и Сосвьвинская культбазы на Омском Севере». Результаты своих исследований научный сотрудник осветил по радиовещанию. По радио была прочитана лекция «Поездка на Север для сбора материалов по истории и быту ханты и манси» [11].

В 1936 г. И.И. Авдеев опубликовал на русском языке медвежьи песни сосьвинских и ляпинских манси. [1]. В книге были собраны песни и драматические представления, отображающие мир животных и взаимоотношения с человеком. Переводы мансийского фольклора Авдеевым были сделаны с соблюдением всех стилистических особенностей мансийского фольклорного языка. И.И. Авдеев в предисловии своей книги сообщил, что он совершил две фольклорные экспедиции к манси: в 1933 году на реку Северная Сосьва и в 1934 году на реку Ляпин, где еще бытовали медвежьи праздники. Ученый упомянул в книге, что мансийский язык изучил в Ленинграде у профессора А.И. Емельянова, одного из основателей мансийской письменности, и у студента Института народов Севера Михаила Гындыбина, манси из Нурьинских юрт (р. Сосьва) Березовского района [1, с. 3].

Опубликованная книга И.И. Авдеевым книга «Песни народа манси» не вызвала в печати и в научных кругах больших обсуждений. В 1937 году в первом номере журнала «Советская Арктика» была напечатана статья фольклориста И.С. Гудкова «О книгах фольклора народов Севера», где автор отметил работу Ивана Ивановича Авдеева: «Омским областным издательством ОГИЗа выпущена интересная книга молодого этнографа, научного работника Тобольского музея И.И. Авдеева - «Песни народа манси». Авдеевым собраны мансийские старые и новые песни и драматические представления. В этих песнях ярко отражена жизнь манси до революции, находившихся под каблуком русского и зырянского эксплуататора-купца. Отражены и ростки борьбы против угнетателей (см. песни «о назойливом купце» и «купце и бедняке», стр. 114-120). Социалистическое строительство на Крайнем Севере нашло отражение в песне «о новой жизни» (стр. 121 - 122). В ней говорится об Октябрьской революции, которая принесла «манси радость, князьям гибель». Далее в ней поется про зажиточную жизнь, являющуюся стимулом к росту грамотности и культуры. Все тексты печатаются впервые, если не считать их публикации в тобольской газете «Советский Север». Они собраны автором и переведены с вогульского языка подстрочником. К недостаткам перевода можно отнести тяжеловесность. Очень музыкальный ритм вогульского фольклора в подстрочном переводе на русский язык потерял свою поэтичность, и читатель может составить неправильное мнение о народной поэзии вогулов, тогда как они являются одним из наиболее поэтически одаренных народов Крайнего Севера. Тексты, собранные И.И. Авдеевым, необходимо было дать опытному переводчику или печатать его подстрочники с национальным текстом. Вводная статья Авдеева не дает анализа мансийского народного творчества» [7, с. 101].

Иван Иванович Авдеев многие явления из жизни народов Крайнего Севера, в частности шаманизм и медвежьи праздники, пытался исследовать как фольклорист, и прежде всего, как этнограф, и старался исключать классовых оценок. И.И. Авдеев отмечал, что в фольклоре происходят существенные изменения, уходят в прошлое обрядовая поэзия, шаманские песнопения, заговоры. «Мансийский фольклор ждет еще своего исследователя и собирателя. Работа над ним в высшей степени плодотворна: она дает богатый материал этнографу, ставит интересные проблемы перед историком, отводит к древнейшим языковым пластам лингвиста. Она имеет 
не только чисто научный интерес, но и интерес практический; нужно поднимать экономический и культурный уровень народности... Необходимо поставить во всю широту вопрос об использовании художественных достижений устного творчества народностей Севера, в процессе создания художественной литературы этих народностей» $[2$, с. 170].

\section{Зак^ючение}

Изменения политической обстановки в обществе в 1930-е гг. отразилось на работе коллектива Тобольского музея. Творческие порывы оценивались чаще всего как отход от циркуляров, нарушение классовой политики. Этнография как самостоятельная наука должна была быть преобразована до роли вспомогательной исторической дисциплины. Это изменение сочеталось с жестокими репрессиями на ученых, которые посвящали свои жизни служению этой науке. В 1936 году в музее была организована выставка, посвящённая прошлому края. Однако эта выставка была подвергнута критике. На страницах газеты «Тобольская правда» была опубликована статья, которая была направлена на осуждение научной деятельности музейных сотрудников. Аресты сотрудников Тобольского музея, органы НКВД начали производить в феврале 1937 года «делу о контрреволюционной организации социал-революционеров в Тобольском музее». [8, с. 70].
После публикации статьи в газете «Тобольская правда», научная деятельность И.И. Авдеева в музее была минимизирована. В 1937 году И.И. Авдеев занимался передачей этнографических экспонатов (предметы одежды народов Севера из меха) Тобольского музея, хранившихся в Тюменском музее в Омский областной музей. 29 марта 1937 г. в Тобольском музее был составлен акт о передаче экспонатов отдела природы: «мы нижеподписавшиеся бывший заведующий отделом природы Авдеев И.И. и вновь назначенный на заведывание отделом природы Тарунин М.П., составили настоящий акт в том, что Авдеев сдал, а Тарунин принял следующие экспонаты по витринным описям» [5].

6 августа 1937 года Иван Иванович Авдеев, заведующий дореволюционным отделом Тобольского музея, был арестован. 11 сентября 1937 г. тройка Омского УНКВД вынесла приговор. 15 сентября 1937 года И.И. Авдеев был расстрелян. Реабилитирован 1 сентября 1956 г. [8, с. 70].

Имя Ивана Ивановича Авдеева долгое время было забыто в отечественной этнографии. Исследование биографии И.И. Авдеева даёт возможность воссоздать развитие науки этнографии в СССР. Актуальным остаётся вопрос дальнейшего исследования биографии И.И. Авдеева: выявления места учебы, изучение всех материалов этнографических экспедиций, организованных исследователем.

\section{ЛИТЕРАТУРА}

1. Авдеев И.И. Песни народа манси. Омск: Омоблгиз, 1936. 127 с.

2. Авдеев И.И. Драматические представления на медвежьем празднике у манси // Советский Север. 1935. № 3-4. С. 169 -174.

3. Авдеев И.И., И.П. Струкова. Тобольские и Тюменские татары. Историко-этнографический очерк. Тобольск, 1937 // Научный архив Тобольского историкоархитектурного музея-заповедника. НА-204.

4. Белич И.В., Перевалова Е.В., Тычинских З.А. Этнографическое собрание Тобольского музея. Тобольск, 1998 // Научный архив Тобольского историко-архитектурного музея-заповедника. НА-1988.

5. Акт от 4 июня 1937 года о передаче этнографических материалов в Тобольский музей // Научный архив Тобольского историко-архитектурного музея-заповедника. НА-374.

6. Государственный архив в г. Тобольске. Ф.Р-1549. Оп. 1. Д. 1. Лл. 13-14.

7. Гудков И.С. О книгах фольклора народов Севера // Советская Арктика. 1937. №1. С. 99 -103.

8. Загороднюк Н.И. Репрессированное слово: Очерки истории репрессивной политики Советского государства в отношении интеллигенции в Тюменском крае. Тобольск: ТГСПА им. Д.И. Менделеева, 2013. 147 с.

9. Иванов С.В. По музеям Западной Сибири // Советская этнография. 1935. № 1. С. $114-116$.

10. Отчёт о работе музея. Тобольск, 1935 // Научный архив Тобольского историко-архитектурного музея-заповедника. НА-1389/1-20.

11. Переписка, планы и отчёты работы музея. Тобольск, 1936 // Научный архив Тобольского историко-архитектурного музея-заповедника. НА-1400/1-20.

12. Переписка, планы и отчёты работы музея. Тобольск, 1937 // Научный архив Тобольского историко-архитектурного музея-заповедника. НА-1401/1-20.

13. Правила внутреннего распорядка по Тобольскому государственному музею на 1935 г. Тобольск, 1935 // Научный архив Тобольского историко-архитектурного музея-заповедника. НА-420/7.

14. Протокол №4 производственного совещания Тобольского государственного музея от 25 октября 1935 г. Тобольск, 1935 // Научный архив Тобольского историко-архитектурного музея-заповедника. НА-420/11.

15. План и содержание работы научного сотрудника Тобольского музея - Авдеева во время экспедиции к татарам Тобольского района от 23 декабря 1935 г. Тобольск, 1935 // Научный архив Тобольского историко-архитектурного музея-заповедника. НА-420/12.

16. Смета на командировку к Тобольским татарам научного сотрудника музея Авдеева от 22 декабря 1936 г. Тобольск, 1936 // Научный архив Тобольского 
историко-архитектурного музея-заповедника. НА-420/13.

17. Личный состав Тобольского музея. Тобольск, 1935 // Научный архив Тобольского историко-архитектурного музея-заповедника. НА-1387/1-20.

18. Научная переписка. Тобольск, 1936 // Научный архив Тобольского историко-архитектурного музея-заповедника. НА-1408.

19. Фольклор ханты и манси // Научный архив Тобольского историко-архитектурного музея-заповедника. НА-169.

( ) Абдуллина Яна Борисовна (yana.abdullina.92@mail.ru).

Журнал «Современная наука: актуальные проблемы теории и практики»

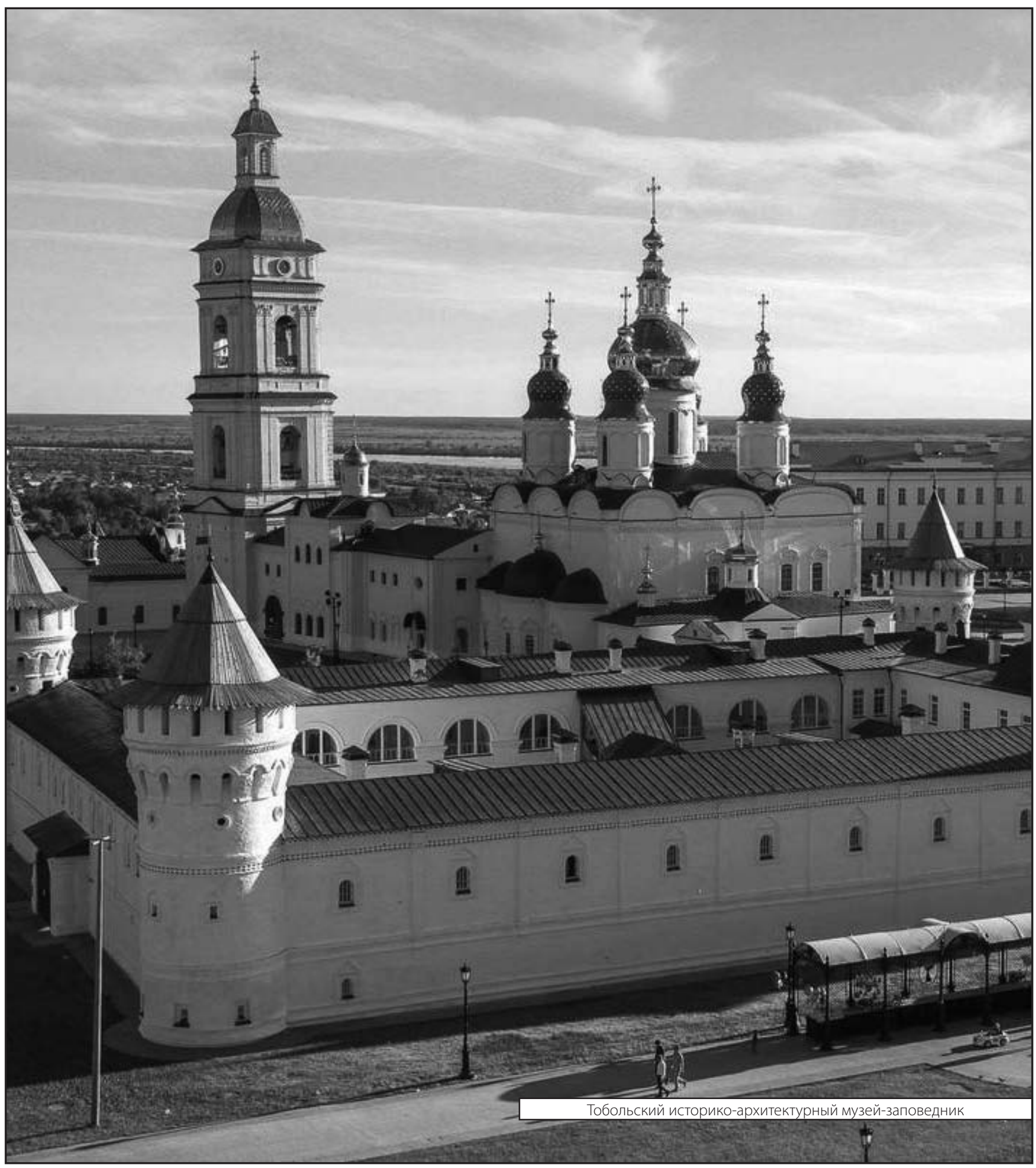

